374316

Antonigaevessi has an article on this subject in Ricercr Screystica e Ricostruzione (Rome), December 1945, which deals with some of the chief points Asent? the reconstruction of industries in Italy Qf the evils which have followed the Fascist negime. A comparison of the industrial life in other coundies-in particular in Switzerland-with that of Italy shows the inherent weakness in the system of the latter. The necessity of scientific-experimental research applied to industrial reconstruction is urgent if the maximum efficiency and output are to be realized, and there must be collaboration between the technical expert and the manufacturer. Although there may be various objections on the grounds of expense, difficulty of training technicians, etc., Revessi waives these aside, and advocates a slow but sure development, never losing sight of the ultimate goal, which is vital if Italy is to recover her positionthe export of her products. There must be no delusions about an immediate recovery of the export trade which Italy enjoyed before the Fascists destroyed it ; nevertheless, by rationalization of industry and by proper organisation, it is possible for her to secpre a high position in the industrial world. Astron Observatfy of Madrid (Bol. Ast. Observ. Madrid, 3, Ap w ; 194 is taken up with statistics relating to suspots sen from the Observatories of Madrid, Valoncia and also Cartuja (Granada), and a résumé of the results is given on pp. 18-25. Much interesting information is provided on the observations of Mars during the 1941 opposition, the work being carried out with the $41-\mathrm{cm}$. Grubb equatorial, focal length 5 metres, which was specially suitable for this type of work. This portion is illustrated by diagrams and also by a number of photographs of the planet taken between September 15 and November 1, 1941. The results of the occultations of thirty stars observed by M. Martín Lorón in 1945 are also reported.

\section{Archæblogy in Africa}

Mr. Thurston $\$$ Aw, until recently an officer in the Gold Coest If ducational Service, has written a very useful arcle (Mem. xxi, International African

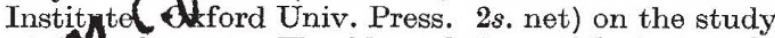
of Aide's past. The idea of the article is to help the dverage person in Africa who has had no special training in archæology to know what to look for and what to do, so that useful information can be obtained. Of its kind the work is one of the most serviceable that hag been produced.

\section{Leicester Museymisuchools Service}

OF the fepd mental reports in the forty-first annual repoff(April 1, 1944-March 31, 1945) recently issued by the Leicester City Museum and Art Gallery, that fiche Schools Service is of particular and gen Ad interest. During the period under review, clastes were instructed in the main museum as well as in the branch museums; special visits were arranged for blind and deaf children, and the loan collections (which include museum specimens, models, dioramas, charts, etc., covering most school subjects) were extended to evacuated schools. Army units in the area made use of the same collections in the development of Forces educational sehemes, and a collection of picture reproductions was extensively used in courses on the appreciation of art. In conjunction with Dr. Boley, of the Psychology Depart. ment of the Leicester Education Committee, two members of the staff instructed special classes in the use and construction of puppets for puppet shows. The children themselves took part in these proceedings, but the exact intent of, or the conclusions drawn from, the results of these activities are not reported. The Museum school service at Leicester has been active and progressive for many years and most, if not all, subsequent and similar schemes elsewhere have been based upon it. That the Leicester methods and results are of interest to outside educational institutions and other bodies is shown by the reference to visitors from London, Nottingham, Glasgow, and the research department of the National Association of Local Government Officers. Further, inspectors from the Board of Education went to observe them, and this fact, especially, points to the possibility of future developments in this work, not only in Leicester, but also wherever suitable museum collections exist.

\section{Announcements \\ DR. T. Dixon has been appointed professor of biochenistry in the Royal Medical College, Baghdad. \\ As from November 1, Dr. N. Hamilton Fairley,} who tales up his appointment as Wellcome professor of tropical medicine in the University of London, will cease to be director of the Wellcome Laboratories of Thopical Medicine, but will become consultant in tropical medicine to the Wellcome Foundation. Brigadier John S. K. Boyd, at present director of pathology, War Office, will become director of the Wellcome Laboratories of Tropical Medicine.

MISS MARIoN Gosser, chief cataloguer at the Science/Library, South Kensington, has been appoint librarian of the Atomic Energy Research Establishment at Harwell, near Didcot. Miss Gosset trkes up her new appointment on September 18.

THE following appointments, promotions and transfers iye the Colonial Services have recently been made : A. A. Blane, to be agricultural officer, Gold Coast J. A. R. Maclean, to be chemist, West Africa Cocga Research Institute, Gold Coast; G. Paton, to by agricultural officer, Nyasaland; G. B. Rattray, to be agricultural officer, Kenya; R. B. Reid, to be agricultural officer, Northern Rhodesia; E. A. Anderson, to be assistant conservator of forests, Gold Coast; S. J. Mayne, to be geologist, Tanganyika; P. R. Wilkinson, to be entomologist (tsetse), Uganda ; W. E. Freeman (botanist, Nigeria), to be senior botanist, Nigeria ; E. J. Gregory (agricultural officer, Uganda), to be senior agricultural officer, Uganda; R. H. Le Pelley (entomologist, Kenya), to be senior entomologist, Kenya; T. T. Brand (senior assistant conservator of forests, Nigeria), to be conservator of forests, Nigeria ; G. S. Cansdale (assistant conservator of forests, Gold Coast), to be senior assistant conserva. tor of forests, Gold Coast ; A. J. Cox (senior assistant conservator of forests, Gold Coast), to be conservator of forests, Gold Coast; F. G. Harper (assistant conservator of forests, Gold Coast), to be senior assistant conservator of forests, Gold Coast; D. Kinloch (assistant conservator of forests, Gold Coast), to be senior assistant conservator of forests, Gold Coast. 